\title{
PENEMUAN HUKUM OLEH HAKIM DAN IMPLIKASI TERHADAP PERKEMBANGAN PRAPERADILAN
}

\author{
Oleh: Wahyu Iswantoro \\ Calon Hakim pada Pengadilan Negeri Ende, \\ Jalan Raya El Tari Kabupaten Ende, Flores Provinsi Nusa Tenggara Timur
}

\begin{abstract}
ABSTRAK
Hakim sebagai aktor penegak hukum dan keadilan harus mampu mengikuti perkembangan hukum yang berkembang di dalam masyarakat. Dengan kewenangannya seorang Hakim harus mampu menetapkan hukum yang semula hukumnya tidak ada menjadi ada, hal itu dilakukan dengan menggunakan metode penemuan hukum (Rechtsvinding) yang secara yuridis harus dapat dipertanggungjawabkan. Penemuan hukum oleh Hakim dalam kaitan dengan perluasan objek serta ruang lingkup Praperadilan semakin hari semakin luas dan bertambah. Pada awalnya muncul dari penemuan hukum oleh Hakim Praperadilan melalui pertimbangan hukum dalam putusannya, dan bahkan hingga saat ini telah ada 4 (empat) Putusan yang dikabulkan oleh Mahkamah Konstitusi yang memperluas ruang lingkup dan objek praperadilan. Hal tersebut tentu menimbulkan implikasi dan permasalahan, apakah sebenarnya penemuan hukum tersebut benar-benar sesuai dengan kebutuhan dan tuntutan perkembangan hukum dimasyarakat. Penelitian ini menggunakan metode penelitian yurudis normatif.
\end{abstract}

Kata Kunci: Penemuan Hukum, Hakim, Praperadilan.

\begin{abstract}
Judges as law enforcement and justice actors must be able to keep abreast of the growing laws in society. The judge with his or her authority must be able to enact a law that was originally no law to exist, it is done by using the method of legal discovery (Rechtsvinding) which juridically must be accountable. The discovery of the law by the Judge in relation to the expansion of the object and the scope of Pretrial Justice increasingly widespread and growing. At first emerged from the discovery of the law by the Judge of Pretrial through the legal considerations in its verdict, and even until now there have been 4 (four) Decisions granted by the Constitutional Court which extends the scope and object of pre-trial. It's certainly raises the implications and problems, whether the actual discovery of the law is really in accordance with the needs and demands of legal development in the society. This research use normative law research.
\end{abstract}

Keywords: Discovery of Law, Judge, Pretrial.

\section{A. Pendahuluan}

Dari sudut pandang sebagian kalangan hakim, mungkin hakim praperadilan dalam Putusan Nomor 38/Pid.Prap/2012/PN.Jkt.Sel dapat dikatakan sebagai sosok yang sangat berani dan progresif, sebab melalui penemuan hukumnya, ia telah mencipta- kan norma hukum baru di luar ketentuan Pasal 1 angka 10 Kitab Undang-undang Hukum Acara Pidana (KUHAP) dengan menyatakan penetapan tersangka sebagai bagian dari objek praperadilan. Namun berbeda dari sudut pandang sebagian besar tersangka yang menganggap sosok hakim praperadilan 
tersebut sebagai sosok pahlawan keadilan, karena melalui ketukan palunya tercipta sarana dan upaya untuk lepas dari labelisasi status tersangka oleh penyidik dengan menguji keabsahannya melalui permohonan praperadilan pada pengadilan negeri.

Hakim sebagai aktor penegak hukum dan keadilan harus mampu mengikuti perkembangan hukum yang berkembang di dalam masyarakat, sebab seringkali dinamika yang muncul dimasyarakat jauh lebih cepat berkembang dari tatanan hukumnya sendiri. Beberapa perkara yang diajukan ke Pengadilan di antaranya terdapat perkara yang aturan hukumnya sendiri tidak ada atau belum dibuat, dan oleh karena Hakim tidak boleh menolak perkara dengan alasan tidak ada dasar hukumnya, dengan demikian seorang Hakim dengan kewenangannya harus mampu menetapkan hukum yang semula hukumnya tidak ada menjadi ada. Sebagai perwujudan pilar yudikatif, hakim dibekali dengan kewenangan istimewa untuk dapat menciptakan norma hukum (judge made law) melalui mekanisme penemuan hukum (Rechtsvinding) dengan dasar sebagaimana tersirat dalam Pasal 5 ayat (1) UU No. 48 Tahun 2009 tentang Kekuasaan Kehakiman (UU Kekuasaan Kehakiman). Kewenangan untuk dapat menggali, mengikuti dan memahami nilai-nilai hukum dan rasa keadilan dalam masyarakat tentu harus disertai dengan pola berpikir yang progresif, kecerdasan spiritual, serta intuisi hakim dalam menyelesaikan setiap perkara yang diadilinya.

Hakim dalam melakukan penemuan hukum harus benar-benar mempertimbangkan berbagai aspek, sebab penemuan hukum dalam putusan pengadilan tidak menutup kemungkinan menjadi yurisprudensi dijadikan preseden oleh hakim-hakim selanjutnya.
Penemuan hukum oleh hakim harus berdasarkan pada tuntutan kenyataan bahwa telah benar-benar terjadi kekosongan hukum, dan masyarakat membutuhkan keadilan dengan mempercayakan penyelesaian permasalahannya melalui sarana pengadilan dan hakim. Hal tersebut sejalan dengan pendapat Soejono Koesoemo Sisworo: "Bahwa hakikat penemuan hukum, yaitu selalu berkaitan dengan situasi dan kondisi masyarakat dan tetap dalam lingkungan sistem hukumnya." ${ }^{1}$

Penemuan hukum oleh Hakim dalam kaitan dengan perluasan objek serta ruang lingkup Praperadilan semakin hari semakin luas dan bertambah, hal tersebut pada awalnya muncul dari penemuan hukum oleh Hakim Praperadilan melalui pertimbangan hukum dalam putusannya, dan juga telah terdapat 4 (empat) Putusan Mahkamah Konstitusi (MK) terkait Praperadilan sebagai objek judicial review nya dan amar putusannya pun memperluas ruang lingkup dan objek praperadilan itu sendiri. Dewasa ini, objek praperadilan telah mengalami perluasan dari yang telah diatur dalam Pasal 1 butir 10 KUHAP, perluasan tersebut di antaranya dikarenakan oleh beberapa Putusan MK sebagai berikut: 1). Putusan MK Nomor 21/PUU-XII/2014 (Penetapan Tersangka sebagai obyek Praperadilan): ${ }^{2} 2$ ). Putusan MK Nomor 102/PUU-XIII/2015 (Ketentuan Gugurnya Permohonan Praperadilan): ${ }^{3}$ 3). Putusan MK Nomor 109/PUU-XIII/2015 (Pembatasan Ruang

1 Otje Salman, Filsafat Hukum Perkembangan dan Dinamika Masalah, (Bandung: PT Refika Aditama, 2012), hlm 61.

2 Lihat Putusan Mahkamah Konstitusi Republik Indonesia Nomor 21/PUU-XII/2014.

3 Lihat Putusan Mahkamah Konstitusi Republik Indonesia Nomor 102/PUU-XIII/2015. 
Lingkup Hukum Materil Praperadilan); ${ }^{4}$ 4). Putusan MK Nomor 130/PUUXIII/2015 (Ketentuan Penyerahan SPDP); ${ }^{5}$ dan juga penemuan hukum oleh hakim praperadilan melalui putusan-putusan sebagai berikut: 1). Hakim Pengadilan Negeri Jakarta Selatan dalam Putusan Nomor 38/Pid.Prap/2012/PN.Jkt.Sel. (Penetapan Tersangka sebagai obyek Praperadilan); ${ }^{6}$ 2). Hakim Pengadilan Negeri Jakarta Selatan dalam Putusan Nomor 04/Pid.Prap/2015/PN.Jkt.Sel. (Penetapan Tersangka sebagai obyek Praperadilan); ${ }^{7}$ 3). Hakim Pengadilan Negeri Jakarta Selatan dalam Putusan Nomor 97/Pid.Prap/2017/PN.Jkt.Sel. (Penetapan Tersangka sebagai obyek Praperadilan); ${ }^{8}$ 4). Hakim Pengadilan Negeri Ende, Kelas II, Flores NTT dalam Putusan Nomor 02/Pid.Prap/2018/ PN.End (Pengehentian Penyelidikan sebagai obyek dari Praperadilan) $;^{9}$ 5). Hakim Pengadilan Negeri Jakarta Selatan dalam Putusan Nomor 24/Pid.Prap/2018/ PN.Jkt.Sel. (Pengehentian Penyelidikan sebagai obyek Praperadilan). ${ }^{10}$

Dengan demikian, dari penemuan hukum dalam beberapa putusan praperadilan sebagaimana diuraikan tersebut telah menyebabkan perluasan ruang lingkup dan objek praperadilan, hal

4 Lihat Putusan Mahkamah Konstitusi Republik Indonesia Nomor 109/PUU-XIII/2015.

5 Lihat Putusan Mahkamah Konstitusi Republik Indonesia Nomor 130/PUU-XIII/2015.

6 Lihat Putusan Hakim Praperadilan pada Pengadilan Negeri Jakarta Selatan Nomor 38/Pid.Prap/2012/PN. Jkt.Sel.

7 Lihat Putusan Hakim Praperadilan pada Pengadilan Negeri Jakarta Selatan Nomor 04/Pid.Prap/2015/PN. Jkt.Sel.

8 Lihat Putusan Hakim Praperadilan pada Pengadilan Negeri Jakarta Selatan Nomor 97/Pid.Prap/2017/PN. Jkt.Sel.

9 Lihat Putusan Hakim Praperadilan pada Pengadilan Negeri Ende Nomor 02/Pid.Prap/2018/PN.End.

10 Lihat Putusan Hakim Praperadilan pada Pengadilan Negeri Jakarta Selatan Nomor 24/Pid.Prap/2018/PN. Jkt.Sel. tersebut tentu menimbulkan implikasi dan permasalahan, apakah sebenarnya penemuan hukum tersebut benar-benar sesuai dengan kebutuhan dan tuntutan perkembangan hukum di masyarakat, ataukah ada tujuan lain yang justru dapat menguntungkan pihak-pihak yang berhadapan dengan hukum agar dapat lepas/bebas dari ancaman pidana. Dari latar belakang sebagaimana diuraikan di atas, maka Penulis dapat memotret dua permasalahan penting untuk dikaji dan dianalisa lebih mendalam, yakni terkait: 1. Apakah penemuan hukum oleh hakim dalam perkara praperadilan telah tepat? 2. Bagaimana implikasi dari penemuan hukum oleh hakim dalam perkara praperadilan?

\section{B. Metode Penelitian}

Jenis penelitian yang digunakan dalam penelitian ini adalah normative law reserach. Dengan pendekatan undang-undang dan pendekatan kasus (case approach) Penelitian hukum normatif berfokus pada inventarisasi hukum positif, asas-asas dan doktrin hukum, penemuan hukum dalam perkara inkonkreto, sistematika hukum, taraf sinkronisasi, perbandingan hukum dan sejarah hukum. ${ }^{11}$ Menurut Peter Mahmud Marzuki: "penelitian hukum terdapat beberapa pendekatan, yaitu pendekatan perundang-undangan (statute approach), pendekatan kasus (case approach), pendekatan historis (historical approach), pendekatan komparatif (comparative approach), dan pendekatan konseptual (conceptual approach)."12 Sesuai dengan permasalahan yang diteliti, maka akan digunakan pendekatan perundang-

11 Abdulkadir Muhammad, 2004, Hukum dan Penelitian Hukum, Jakarta, Citra Aditya Bakti, hlm. 52.

12 Peter Mahmud Marzuki, 2014, Penelitian Hukum, Jakarta, Kencana, hlm. 133. 
undangan (statute approach) dan pendekatan kasus (case approach). Dengan pendekatan pendekatan statute approach, maka akan dikaji hierarki peraturan perundang-undangan dan asas-asas hukum. Sedangkan, pendekatan kasus (case approach) untuk mengetahui ratio legis dan dasar ontologism lahirnya suatu peraturan perundang-undangan. ${ }^{13}$

Penelitian ini menitikberatkan pada data sekunder. Data sekunder merupakan data yang diperoleh secara tidak langsung dari sumber aslinya, diperoleh dari bahan kepustakaan. Bahan hukum primer yang digunakan dalam penelitian ini terdiri dari perundangundangan, catatan-catatan resmi, atau risalah di dalam pembuatan peraturan perundang-undangan dan putusanputusan hakim. Sedangkan, bahan hukum sekunder yang digunakan dalam penelitian ini terdiri dari buku, makalah, jurnal hukum, pendapat para ahli, media massa dan internet.

Teknik pengumpulan data yang digunakan dalam penelitian ini adalah studi kepustakaan, yaitu teknik pengumpulan data dengan cara mengumpulkan bahan-bahan yang berupa buku-buku dan bahan kepustakaan lain yang dibutuhkan. Studi kepustakaan digunakan untuk mendapatkan landasan teori dan informasi melalui bahan yang dijadikan sumber data. Penelitian ini melakukan pengumpulan bahan hukum dengan cara mencari peraturan perundang-undangan yang berkaitan dengan masalah hukum dalam penelitian ini, yakni terkait praperadilan. Selain itu juga dilakukan penelusuranpenelusuran buku-buku hukum yang di dalamnya terdapat teori-teori hukum yang berkaitan dengan masalah yang diteliti. Analisis data merupakan upaya

13 Ibid. hlm 93. untuk menjelaskan dan memaknai data, dengan menggunakan alat bantu berupa teori. Pada dasarnya analisis data adalah: Pertama, kegiatan melakukan klasifikasi/ kategorisasi data berdasarkan tema-tema yang muncul dari catatan lapangan dan temuan penelitian. Kedua, kegiatan melakukan konfirmasi antara teori dan data. ${ }^{14}$ Penarikan kesimpulan dari hasil analisis pembahasan yang sudah terkumpul dilakukan dengan metode analisis kualitatif-normatif, yaitu dengan cara melakukan penafsiran, kolerasi, dan perbandingan terhadap bahan-bahan hukum dan perbandingan konstruksi hukum yang relevan dengan kajian penelitian ini. ${ }^{15}$

\section{Pembahasan}

1. Penemuan Hukum (Rechtsvinding) oleh Hakim dalam Perkara Praperadilan

Hakim harus mampu mengikuti perkembangan nilai-nilai hukum yang berkembang di dalam masyarakat, sebab seringkali dinamika yang muncul di masyarakat jauh lebih cepat berkembang dari tatanan hukumnya sendiri. Beberapa perkara yang diajukan ke pengadilan di antaranya terdapat perkara yang aturan hukumnya sendiri tidak ada atau telah out of date. Dalam kondisi mendesak, apabila terdapat suatu perkara yang diajukan ke muka pengadilan dan hukum positif belum mengatur tentang dasar hukum untuk mengadili perkara tersebut, maka hakim sebagai perwujudan pilar yudikatif yang dianggap tahu hukum dapat mencari dan menemukan hukum

14 Sulistyowati Irianto, 2011, Praktek Penelitian Hukum: Perspeftif Sosiolegal dalam Bettina Yahya, dkk, 2017, Urgensi dan Mekanisme Pengembalian Aset Hasil Tindak Pidana Korupsi, Puslitbang Hukum dan Peradilan Badan Diklat Kumdil Mahkamah Agung Republik Indonesia, Jakarta, Puslitbang Hukum dan Peradilan Mahkamah Agung RI, hlm. 35.

15 Ibid. 
(rechtsvinding) serta menciptakan norma hukum (judge made law).

Istilah hakim dianggap tahu hukum atau lebih dikenal dengan adegium "Ius Curia Novit" yang dalam terminologi bahasa inggris juga disebut "court knows the law", pertama kali ditemukan oleh para ahli hukum abad pertengahan (legal glossators) dalam tulisan-tulisan tentang hukum Romawi kuno, yang hal tersebut diartikan sebagai kewenangan hakim untuk mencari dan menetapkan suatu hukum, karena hukum tertulis yang dikodifikasikan pada dasarnya tidak akan pernah lengkap, atau dengan kata lain hukum pasti berubah mengikuti perkembangan zaman.

Penemuan hukum oleh hakim seringkali memang dikaitkan dengan aturan bahwa hakim tidak boleh menolak perkara dengan dalih hukumnya tidak ada, sehingga hakim harus mampu menemukan hukum dan menciptakan norma hukum. Karena hakim dianggap tahu hukum, maka hakim dilarang menolak untuk memeriksa, mengadili dan memutus suatu perkara dengan dalih bahwa hukumnya tidak ada atau kurang jelas. ${ }^{16}$ Sejarah hukum di Indonesia mencatat bahwa dalam Pasal 22 Algemene Bepalingen Van Wetgeving Voor Indonesie atau Peraturan Umum Mengenai Perundang-undangan untuk Indonesia, yang menyatakan bahwa "hakim yang menolak mengadili suatu perkara dapat dipidana". ${ }^{17}$ Lebih lanjut, dalam Pasal 859 Rv menyatakan bahwa "hakim yang menolak untuk memberikan penetapan atas suatu permohonan atau putusan atas suatu perkara, maka pihak

16Lihat Pasal 10 ayat (1) Undang-undang Nomor 48 Tahun 2009 tentang Kekuasaan Kehakiman

17 Lihat Pasal 22 Algemene Bepalingen Van Wetgeving Voor Indonesie yang berkepentingan dapat mengajukan aduan". ${ }^{18}$

Hakim dengan kewenangannya harus mampu menetapkan hukum yang semula hukumnya tidak ada menjadi ada, hal itu dilakukan dengan menggunakan metode penemuan hukum yang jika dikaji secara ilmiah (keilmuan) dan secara yuridis maupun teoretis harus dapat dipertanggungjawabkan. Pada dasarnya penemuan hukum (rechtsvinding) itu sendiri dibagi dalam tiga kategori pendekatan, yakni 1) Interpretasi; 2) Konstruksi Hukum; dan 3) Hermeneutika. Dengan demikian menjadi suatu keharusan bagi hakim dalam menemukan hukum untuk menggunakan pendekatan penemuan hukum seperti apa.

Walaupun hakim dilarang menolak untuk memeriksa, mengadili, dan memutus suatu perkara, akan tetapi bukan berarti seorang hakim dapat dengan mudah melakukan penemuan hukum tanpa mempertimbangkan keseimbangan antara unsur kepastian, keadilan, dan kemanfaatan hukum. Hakim harus benar-benar yakin bahwa penemuan hukum tersebut benar-benar dibutuhkan untuk menegakkan keadilan di masyarakat. Ratio Decidenci atau alasan-alasan hukum hakim dalam melakukan penemuan hukum harus sangat tepat. Idealnya dalam mengambil putusan terhadap suatu perkara, hakim mempertimbangkan 4 (empat) elemen, yaitu aspek filosofis, asas-asas hukum, aturan hukum positif, dan budaya masyarakat hukum. Keempat elemen tersebut dimasukan secara proporsional dalam proses pengambilan putusan hukum. ${ }^{19}$

Dalam kaitannya dengan perkara praperadilan, hakim dituntut dapat

18 Lihat Pasal 859 Rv (Rechtsvordering)

19 Dedy Muchti Nugroho, Dandapala Vol.

IV Edisi 1, 2018, hlm 65 
berpikir kritis untuk menerapkan ketiga unsur penting dalam penegakan hukum dan keadilan, yakni mengenai kepastian hukum (pendekatan legalistik), keadilan (pendekatan rechtsvinding), dan kemanfaatan (pendekatan antropologi). Sebab ketiga unsur tersebut sebenarnya menjadi dasar berpikir serta menetukan top of mind seorang hakim dalam memeriksa, mengadili dan memutus perkara praperadilan yang diajukan ke muka pengadilan yang ternyata belum ada aturan hukumnya.

Sejalan dengan hal tersebut, Menurut Ade Saptomo, prinsip-prinsip bagi hakim dalam mengadili perkaraperkara hukum konkret mencakup tiga pendekatan sebagai berikut: ${ }^{20}$

a. Pendekatan Legalistik (Formal) Pendekatan legalistik dimaksud merupakan model yang digunakan oleh hakim dalam menyelesaikan kasus hukum konkret yang telah mengatur secara jelas sehingga hakim mencari, memilah, dan memilih unsurunsur hukum dalam kasus hukum konkret dimaksud dan kemudian dipertemukan dengan pasal-pasal relevan dalam undang-undang dimaksud.

b. Pendekatan Interpretatif Hukum dalam kenyataannya dimungkinkan aturan normatif itu tidak lengkap atau samar-samar. Dalam upaya menegakkan hukum dengan keadilan dan kebenaran, hakim harus dapat melakukan penemuan hukum (rechtsvinding).

c. Pendekatan Antropologis Terhadap kasus hukum konkret yang belum diatur undang-udanng maka hakim harus menemukan hukum dengan cara menggali, mengikuti, dan

20 Ade Saptomo, 2009, Hukum \& Kearifan Lokal, Grasindo, Jakarta, hlm. 54-55. menghayati nilai-nilai hukum yang hidup dalam masyarakat.

Dalam hal hakim memilih menggunakan pendekatan interpretasi hukum dengan melakukan penemuan hukum (rechtsvinding) untuk memeriksa, mengadili dan memutus suatu perkara permohonan praperadilan yang diajukan ke muka pengadilan yang tidak ternyata belum ada aturan hukumnya, hal tersebut tentu akan berdampak kepada aspek kepastian hukum (legal certainty) dan memicu adanya peluang penyalahgunaan wewenang oleh hakim yang justru menguntungkan kepentingan hukum para tersangka/terdakwa, seperti dalam kasus perluasan ruang lingkup praperadilan yang mengakomodir sah atau tidaknya penetapan tersangka, sah atau tidaknya penyitaan dan sah atau tidaknya penggeledahan yang kesemuanya menjadi angin segar bagi para tersangka/terdakwa untuk berbondong-bondong mengajukan permohonan praperadilan.

Penemuan hukum oleh hakim yang berdampak langsung pada perluasan objek serta ruang lingkup praperadilan juga menjadi pemicu bagi hakim-hakim lain untuk melakukan penemuan hukum serupa dalam materi norma hukum yang lain. Padahal yang perlu dipahami adalah tujuan hakiki dari penemuan hukum itu sendiri, yakni guna memenuhi tuntutan rasa keadilan masyarakat yang tidak terakomodir oleh hukum positif. Dengan demikian, seorang hakim harus sangat jeli dan teliti dalam memutuskan untuk melakukan suatu interpretasi hukum dengan melakukan suatu penemuan hukum.

Dengan demikian, penemuan hukum yang dilakukan oleh hakim harus mampu menangkap keadilan hukum (legal justice) dan keadilan masyarakat (social justice), sebab apabila penemuan hukum dilakukan dengan dalih bahwa hukum 
normatif telah gagal meciptakan rasa keadilan, maka penemuan hukum tersebut harus bebas dari unsur kepentingan-kepentingan non hukum. Di sisi lain, perdebatan mengenai penemuan hukum yang dianggap sebagai upaya rule breaking atau keluar dari aturan normatif dan diasumsikan sebagai aliran hukum progresif dan sociological jurisprudence yang mendegradasi aspek kepastian hukum (legal certainty), hal tersebut merupakan suatu hal biasa terjadi sebab bagi para ahli hukum, berbeda dalam pandangan, aliran, pendekatan hukum merupakan suatu keniscayaan untuk memahami hukum secara utuh dan universal.

\section{Implikasi Perkembangan Praperadilan}

Keberadaan pranata praperadilan adalah sebagai bentuk pengawasan dan mekanisme keberatan terhadap proses penegakan hukum yang terkait erat dengan jaminan perlindungan hak asasi manusia, sehingga pada zamanya aturan tentang praperadilan dianggap sebagai bagian dari mahakarya KUHAP. Namun demikian, dalam perjalanannya ternyata lembaga praperadilan tidak dapat berfungsi secara maksimal karena tidak mampu menjawab permasalahan yang ada dalam proses pra-ajudikasi. Fungsi pengawasan yang diperankan pranata praperadilan hanya bersifat post facto sehingga tidak sampai pada penyidikan dan pengujiannya hanya bersifat formal yang mengedepankan unsur objektif, sedangkan unsur subjektif tidak dapat diawasi pengadilan. Hal itu justru menyebabkan praperadilan terjebak hanya pada hal-hal yang bersifat formal dan sebatas masalah, sehingga jauh dari hakikat keberadaan pranata praperadilan. ${ }^{21}$

21 Lihat Putusan MK Nomor 21/PUU-XII/2014, paragraph 3.16 angka 1 huruf a, hlm. 104.
Berkaca pada tuntutan perkembangan hukum, saat ini objek praperadilan telah mengalami perkembangan dari sebagaimana yang telah diatur dalam Pasal 1 angka 10 jo. Pasal 77 KUHAP. Mulai dari penemuan hukum oleh hakim praperadilan Pengadilan Negeri Jakarta Selatan dalam Putusan Nomor 38/Pid.Prap/2012/PN.Jkt.Sel (Penetapan Tersangka sebagai obyek Praperadilan), kemudian ternyata menjadi preseden bagi beberapa putusan praperadilan berikut-nya, bahkan dalam ranah uji materi ke Mahkamah Konstitusi (MK), telah ada beberapa Putusan MK yang menciptakan norma hukum baru yang memperluas objek serta ruang lingkup praperadilan, antara lain sebagai berikut:

1. Putusan MK Nomor 21/PUU-XII/2014 (Penetapan Tersangka, sah atau tidaknya penggeledahan dan penyitaan sebagai obyek Praperadilan);

2. Putusan MK Nomor 102/PUUXIII/2015 (Ketentuan Gugurnya Permohonan Praperadilan);

3. Putusan MK Nomor 109/PUUXIII/2015 (Pembatasan Ruang Lingkup Hukum Materil Praperadilan);

4. Putusan MK Nomor 130/PUUXIII/2015 (Ketentuan Penyerahan SPDP);

Lebih lanjut, selain karena adanya putusan-putusan MK di atas, penemuan hukum oleh hakim praperadilan yang sebelumnya ternyata dijadikan preseden dan yurisprundensi oleh hakim pada Pengadilan Negeri Ende, dalam Putusan Nomor 02/Pid.Prap/2018/PN.End yang pada intinya menyatakan bahwa "Pengehentian Penyelidikan sebagai objek dari Praperadilan, karena penyelidikan merupakan kesatuan rangkaian dengan tindakan Penyidikan". Dengan demikian telah terjadi lagi perluasan ruang lingkup dan objek praperadilan karena penemuan hukum 
oleh hakim dalam putusannya.

Apabila dianalisis lebih lanjut, penemuan hukum dalam Putusan Nomor 38/Pid.Prap/2012/PN.Jkt.Sel. maupun Putusan Nomor 02/Pid.Prap/2018/ PN.End terlihat bahwa telah terjadi pergeseran aliran hukum yang dianut oleh hakim dalam memeriksa, mengadili, dan memutus suatu perkara. Meskipun Indonesia menganut sistem hukum tertulis (civil law system), akan tetapi fakta menunjukkan bahwa Doctrine of Precedent atau dalam bahasa latinnya disebut Stare Decicis telah masuk dalam pertimbangan dan ratio decidenci hakim dalam melakukan penemuan hukumnya, padahal aliran doktrin hukum tersebut adalah manifestasi metodologis dari lahirnya yurisprudensi, yang merupakan sumber hukum dalam sistem hukum Common Law.

Putusan MK Nomor 21/PUU$\mathrm{XII} / 2014$, yang dalam amar putusannya menyatakan bahwa "Pasal 77 huruf $A$ KUHAP tidak memiliki kekuatan hukum mengikat sepanjang tidak dimaknai termasuk penetapan tersangka, penggeledahan dan penyitaan". Dari norma hukum baru yang diciptakan oleh MK, maka timbul permasalahan terkait bagaimanakah kedudukan putusan MK tersebut dalam hierarki sumber hukum formil, mengingat pada hakikatnya, MK tidak memiliki kewenangan untuk menciptakan norma hukum baru. Begitupun dengan norma hukum baru yang diciptakan oleh MK dari putusan ini, nantinya akan menjadi sebuah pertanyaan besar mengenai dimanakan posisi putusan MK dalam hierarki sumber hukum formil di Indonesia, sebab penciptaan norma baru oleh MK di luar proses legislasi seperti yang dilakukan oleh DPR RI masih menjadi perdebatan mengenai kekuatan mengikatnya, sebab hukum positif yang berlaku sebagai sumber hukum formil utama adalah peraturan perundang-undangan yang dibuat oleh DPR selaku legislator. Dengan demikian, beberapa ahli hukum beranggapan bahwa putusan MK hanya menjadi sumber hukum formil yang berupa doktrin ahli hukum atau ada juga yang menyebutnya yurisprudensi, walaupun anggapan itu juga dirasa kurang begitu tepat.

Sejalan dengan hal tersebut di atas, Saldi Isra dalam artikelnya yang berjudul "Negative Legislator" yang pada intinya menyebutkan bahwa MK sebagai negative legislator yakni lembaga peradilan yang berwenang membatalkan suatu undang-undang atau menyatakan suatu undang-undang tidak mengikat secara hukum. ${ }^{22}$ Dengan demikian, seharusnya MK tidak menciptakan suatu norma hukum baru dengan menyatakan penetapan tersangka sebagai bagian dari objek praperadilan, karena hal tersebut di luar wewenang yang dimiliki MK. Apa yang dilakukan MK tersebut justru menjadikan MK berfungsi sebagai "Positive Legislator" seperti halnya fungsi yang dimiliki oleh Dewan Perwakilan Rakyat Republik Indonesia (DPR RI). Di sisi lain, Hakim Konstitusi dalam pertimbangan hukum putusannya bisa dikatakan telah melakukan penemuan hukum (Rechtsvinding), akan tetapi penemuan hukum yang dilakukan oleh Hakim Konstitusi tersebut tidak pada tempatnya, karena hal tersebut berbeda dengan penemuan hukum yang dilakukan oleh Hakim Tingkat Pertama (Judex Factie) yang karena wewenang yang dimilikinya dapat melakukan penemuan hukum dan menciptakan norma hukum baru (judge made law).

Dampak sosilogis dari munculnya norma hukum baru dalam Putusan MK

22 Lihat Saldi Israa, Negative Legislator, artikel diakses pada 8 Mei 2018 dari situs www.saldiisraa.co.id. 
Nomor 21/PUU-XII/2014 tentang penetapan status tersangka sebagai objek gugatan praperadilan adalah menjadikan hal tersebut sebagai kesempatan emas dan meningkatkan animo para tersangka untuk mengajukan praperadilan guna menguji tindakan penyidik dalam menetapkan status tersangka telah sesuai dengan prinsip due process of law atau belum. Sejalan dengan hal tersebut, Zaqiu Rahman, dalam Jurnal Rechtsvinding edisi Juli Tahun 2015 menyatakan bahwa pasca Putusan MK tercatat beberapa tersangka korupsi telah mengajukan permohonan praperadilan atas penetapan dirinya sebagai tersangka. Adapun kasus yang cukup mengundang perhatian masyarakat adalah permohonan praperadilan mantan Walikota Makassar Ilham Arief Sirajuddin di Pengadilan Negeri Jakarta Selatan atas perkara kasus dugaan korupsi terkait kerja sama kelola dan transfer untuk instalasi PDAM Kota Makassar. Dalam putusannya, Hakim Upiek menyatakan, penetapan Ilham Arief sebagai tersangka tidak sah karena KPK tidak bisa menunjukkan alat bukti yang cukup. $^{23}$

Dengan demikian, hal yang perlu segera dilakukan oleh pemerintah dan juga Dewan Perwakilan Rakyat Republik Indonesia (DPR RI) selaku legislator adalah dengan segera mengesahkan Revisi KUHAP dan KUHP untuk meredam gejolak hukum di masyarakat serta agar seluruh masyarakat yang merasa bahwa aturan hukum positif yang saat ini belum mengakomodir rasa keadilan hukum dan keadilan masyarakat dapat segera dipenuhi dengan KUHAP dan KUHP baru yang lebih lengkap. Dengan begitu, masyarakat tidak harus selalu mengajukan permohonan praperadilan yang norma hukumnya tidak ada aturannya yang hal tersebut memicu hakim untuk melakukan penemuan hukum.

\section{Penutup}

Disadari atau tidak, penemuan hukum oleh hakim tentu menimbulkan implikasi dan pengaruh terhadap tatanan hukum yang telah ada (ius contuitutum). Begitupula hasil penemuan hukum oleh hakim yang memperluas objek dan ruang lingkup praperadilan, yang kemudian dalam praktiknya telah menjadi yurisprudensi serta Doctrine of Precedent bagi hakim-hakim selanjutnya dalam memeriksa, mengadili dan memutus perkara. Upaya progresif hakim dalam melakukan penemuan hukum harus diimbangi dengan pendidikan kesadaran hukum dimasyarakat. Sebab sering kali judex factie melakukan penemuan hukum dan menciptakan norma hukum baru di luar ketentuan undang-undang yang hal tersebut justru dapat memicu perdebatan dalam masyarakat umum maupun di dalam kalangan ahli hukum dan para praktisi hukum.

Aspek kepastian hukum, kemanfaatan dan keadilan harus mampu diwujudkan secara berimbang oleh hakim dalam penemuan hukumnya. Terlepas dari perdebatan dalam menyikapi implikasi dari penemuan hukum oleh hakim, Pemerintah harus mengambil sisi positifnya sebagai bahan pembaharuan hukum dalam lus Constituendum. Perkembangan praperadilan yang membawa dampak terhadap perluasa objek dan ruang lingkup, baik karena penemuan hukum (rechtsvinding) maupun yang lahir dari norma hukum atas Putusan MK, dapat dirangkum kedalam sebuah tabel sebagai berikut:

23 Zaqiu Rahman, Jurnal Rechtsvinding, BPHN, Edisi Juli, 2015, hlm. 1. 


\begin{tabular}{|c|c|c|c|}
\hline JENIS & KUHAP & PUTUSAN MK & $\begin{array}{c}\text { PENEMUAN HUKUM OLEH } \\
\text { HAKIM }\end{array}$ \\
\hline $\begin{array}{l}\text { RUANG LINGKUP \& } \\
\text { OBJEK }\end{array}$ & $\begin{array}{l}\text { Pasal } 77 \text { KUHAP: } \\
\text { 1. sah atau tidaknya } \\
\text { suatu penangkapan } \\
\text { dan/atau } \\
\text { penahanan atas } \\
\text { permintaan } \\
\text { tersangka atau } \\
\text { keluarganya atau } \\
\text { pihak lain atas } \\
\text { kuasa tersangka; } \\
\text { 2. sah atau tidaknya } \\
\text { penghentian } \\
\text { penyidikan atau } \\
\text { penghentian } \\
\text { penuntutan atas } \\
\text { permintaan demi } \\
\text { tegaknya hukum } \\
\text { dan keadilan; } \\
\text { 3. permintaan ganti } \\
\text { kerugian atau } \\
\text { rehabilitasi oleh } \\
\text { tersangka atau } \\
\text { keluarganya atau } \\
\text { pihak lain atas } \\
\text { kuasanya yang } \\
\text { perkaranya tidak } \\
\text { diajukan ke } \\
\text { pengadilan. }\end{array}$ & $\begin{array}{l}\text { 1. Putusan MK Nomor } \\
\text { 21/PUU-XII/2014 } \\
\text { "Penetapan } \\
\text { Tersangka, sah atau } \\
\text { tidaknya } \\
\text { penggeledahan dan } \\
\text { penyitaan sebagai } \\
\text { obyek } \\
\text { Praperadilan". } \\
\text { 2. Putusan MK } \\
\text { Nomor 102/PUU- } \\
\text { XIII/2015 } \\
\text { "Ketentuan } \\
\text { Gugurnya } \\
\text { Permohonan } \\
\text { Praperadilan". } \\
\text { 3. Putusan MK Nomor } \\
\text { 109/PUU-XIII/2015 } \\
\text { “Pembatasan Ruang } \\
\text { Lingkup Hukum } \\
\text { Materil } \\
\text { Praperadilan } \\
\text { (Diakuinya Penyidik } \\
\text { Independen KPK)". } \\
\text { 4. Putusan MK Nomor } \\
\text { 130/PUU-XIII/2015 } \\
\text { "Ketentuan } \\
\text { Penyerahan SPDP”. }\end{array}$ & $\begin{array}{l}\text { 1. Hakim Pengadilan } \\
\text { Negeri Jakarta Selatan } \\
\text { dalam Putusan Nomor } \\
\text { 38/Pid.Prap/2012/PN.Jk } \\
\text { t.Sel. } \\
\text { "Penetapan Tersangka } \\
\text { sebagai obyek } \\
\text { Praperadilan". } \\
\text { 2. Hakim Pengadilan } \\
\text { Negeri Ende, Kelas II, } \\
\text { Flores NTT dalam } \\
\text { Putusan Nomor } \\
\text { 02/Pid.Prap/2018/PN.E } \\
\text { nd } \\
\text { "Pengehentian } \\
\text { Penyelidikan sebagai } \\
\text { obyek dari } \\
\text { Praperadilan). }\end{array}$ \\
\hline
\end{tabular}




\section{DAFTAR PUSTAKA}

\section{A. Buku}

Marzuki, Mahmud Peter, Penelitian Hukum, (Jakarta: Kencana, 2014).

Muhammad, Abdulkadir, Hukum dan Penelitian Hukum (Jakarta: Citra Aditya Bakti, 2004).

Nugroho, Muchti Dedy, Majalah Dandapala Vol. IV Edisi 1 (Jakarta: Dirjen Badilum,2018).

Salman, Otje, Filsafat Hukum Perkembangan dan Dinamika Masalah (Bandung: PT Refika Aditama, 2012).

Saptomo, Ade, Hukum \& Kearifan Lokal (Jakarta: Grasindo, 2009).

Yahya, Bettina, dkk, Urgensi dan Mekanisme Pengembalian Aset Hasil Tindak Pidana Korupsi, Puslitbang Hukum dan Peradilan Badan Diklat Kumdil Mahkamah Agung Republik Indonesia (Jakarta: Puslitbang Hukum dan Peradilan Mahkamah Agung RI, 2017).

Yanto, Hakim Komisaris dalam Sistem Peradilan Pidana (Yogyakarta: Kepel Press, 2013).

\section{B. Artikel Dalam Jurnal}

Rahman, Zaqiu, Jurnal Rechtsvinding, Edisi Juli, 2015, HIm 1, BPHN, Jakarta.

\section{Artikel Internet}

Isra Saldi, Negative Legislator, www.saldiisraa.co.id, diakses pada 8 Mei 2018.

\section{Peraturan Perundang-undangan}

Undang-Undang Dasar Negara Republik Indonesia Tahun 1945.

Undang-Undang Nomor 8 Tahun 1981 tentang Kitab Undang-Undang Hukum Acara Pidana (KUHAP).

Undang-Undang Nomor 48 Tahun 2009 tentang Kekuasaan Kehakiman.

Algemene Bepalingen Van Wetgeving Voor Indonesie.

Rv (Rechtsvordering).

\section{E. Putusan Pengadilan}

Putusan Mahkamah Konstitusi Republik Indonesia Nomor 21/PUU-XII/2014.

Putusan Mahkamah Konstitusi Republik Indonesia Nomor 102/PUU-XIII/2015.

Putusan Mahkamah Konstitusi Republik Indonesia Nomor 109/PUU-XIII/2015. 
Putusan Mahkamah Konstitusi Republik Indonesia Nomor 130/PUU-XIII/2015.

Putusan Hakim Praperadilan pada Pengadilan Negeri Jakarta Selatan Nomor 38/Pid.Prap/2012/PN.Jkt.Sel.

Putusan Hakim Praperadilan pada Pengadilan Negeri Jakarta Selatan Nomor 04/Pid.Prap/2015/PN.Jkt.Sel.

Putusan Pengadilan Negeri Jakarta Selatan Nomor Putusan 71/Pid.Pra/2017/PN JKT.SEL.

Putusan Hakim Praperadilan pada Pengadilan Negeri Jakarta Selatan Nomor 97/Pid.Prap/2017/PN.Jkt.Sel.

Putusan Hakim Praperadilan pada Pengadilan Negeri Ende Nomor 02/Pid.Prap/2018/PN.End.

Putusan Hakim Praperadilan pada Pengadilan Negeri Jakarta Selatan Nomor 24/Pid.Prap/2018/PN.Jkt.Sel. 